\title{
Characterization of Biomethanol-Biodiesel-Diesel Blends as Alternative Fuel for Marine Applications
}

\author{
Zhongcheng Wang ${ }^{1}$, Tatjana Paulauskiene ${ }^{2, * \mathbb{D}}$, Jochen Uebe ${ }^{2} \mathbb{D}$ and Martynas Bucas ${ }^{3}$ \\ 1 Merchant Marine College, Shanghai Maritime University, Shanghai 201306, China; zcwang@shmtu.edu.cn \\ 2 Engineering Department, Faculty of Marine Technology and Natural Sciences, Klaipeda University, \\ H. Manto 84, 92294 Klaipeda, Lithuania; jochen.uebe@ku.lt \\ 3 Marine Research Institute, Klaipeda University, H. Manto 84, 92294 Klaipeda, Lithuania; \\ martynas.bucas@jmtc.ku.lt \\ * Correspondence: tatjana.paulauskiene@ku.lt
}

Received: 18 August 2020; Accepted: 21 September 2020; Published: 22 September 2020

\begin{abstract}
The ambitious new International Maritime Organization (IMO) strategy to reduce greenhouse gas emissions from ships will shape the future path towards the decarbonization of the fleet and will bring further ecological challenges. In order to replace the larger oil-based part of marine fuel with components from renewable sources, it is necessary to develop multi-component blends. In this work, biomethanol and biodiesel with two additives-dodecanol and 2-ethylhexyl nitratein 20 blends with marine diesel oil (MDO) were selected as alternative components to replace the pure marine diesel oil-based part of marine fuel. For this purpose, two base blends of diesel and biodiesel with and without additives were produced with biomethanol from 0 to $30 \%$ (volume basis). Of all the blends, the blends with $5 \%$ (volume basis) methanol had the best property profile in terms of density, kinematic viscosity, calorific value, cloud point, and cetane index according to the ISO 8217:2017 standard (DMB grade) in compliance with the IMO requirements for marine fuels. However, the flash point must be increased. The boiling behavior of the blends was also investigated. A cluster analysis was used to evaluate the similarity between the blends based on their different physical properties.
\end{abstract}

Keywords: marine fuel; alternative fuel; biomethanol; biodiesel; marine diesel oil; methanol-diesel blend; multivariate analysis

\section{Introduction}

Maritime transport is crucial for the global economy, as more than $80 \%$ of world trade is by sea [1], and the authors of [2] concluded that it is the most cost-effective way to transport goods around the world. Marine engines have a very high fuel consumption due to their size [3]. Therefore, they also have high particulate and NOx emissions [4]. World Health Organization estimates [5] give an alarming number of several million deaths per year from air pollution, which was also confirmed by [6]. The reformulation of conventional diesel fuel is an effective means of reducing pollutants, but this is a difficult task due to the constant specific fuel consumption of diesel. In general, there are complicated relationships between the molecular structure and the physical properties of diesel fuel [7].

The use of alternative fuels, such as alcohols and biodiesel, could reduce not only diesel consumption but also pollutants, especially particulate emissions [8]. The use of alcohols and biodiesel in conventional fuels [9] is developing into an alternative fuel due to its ease of production and environmental friendliness [10]. These additives can reduce the emissions of air pollutants, especially particulate matter [8].

Biodiesel is non-toxic, easily biodegradable, and has no sulphur and aromatic content [11]; it also has a high flash point and cetane index, and it has better lubricating properties than fossil 
diesel [12]. As an additive to improve the quality of diesel, biodiesel has become attractive due to its environmental friendliness, high flash point $\left(\sim 150{ }^{\circ} \mathrm{C}\right)$ and cetane index that is higher than conventional petroleum diesel fuel, good lubricity, biodegradability, and low toxicity [13]. The use of biodiesel reduces particulate emissions and CO emissions [14]. Methanol can now be $100 \%$ produced from renewable sources $[15,16]$. Alcohols have a higher oxygen content than fossil fuels; this helps internal combustion engines to achieve a degree of combustion closer to completion and thus to reduce soot emissions [17-19]. The stability of alcohol-diesel blends is mainly influenced by low temperatures, water content, and alcohol content [20]. Therefore, additives are very important to avoid phase separation [21-23]. Dispersing additives [24] such as long-chain alcohols like dodecanol, which are amphiphilic like a surfactant and are compatible with both diesel and short-chain alcohols such as methanol, are used. Additionally, 2-ethylhexyl nitrate is mainly used as an ignition booster [25], but due to its amphiphilic molecular structure, it can also act as a dispersing agent.

Biodiesel can be used in diesel engines without any modifications to the engine system because its combustion properties are very similar to those of conventional diesel [4]. The addition of sulphur-free biodiesel has proven to be one of the most effective ways of reducing the high sulphur content of marine diesel oil (MDO) [26].

However, problems, such as phase separation in the fuel mixture, may occur, but this could be solved by dispersive additives such as dodecanol [22]. To replace as much fossil fuel as possible with renewable components, more multi-component fuels are required. The most suitable formulations, proportions, and additives for alternative fuels are still being sought $[1,8,27]$.

The aim of the present study was to experimentally investigate the performance of the physical characteristics of diesel with the addition of biodiesel, biomethanol, and the additives dodecanol and 2-ethylhexyl nitrate compared with the listed values of a diesel according ISO 8217:2017 (DMB grade). In addition, a multivariate statistical analysis was carried out to support the verification by measurements of the physical properties [28].

\section{Materials and Methods}

Twenty blends based on diesel (JSC "Gindana") with different proportions of biomethanol (Sigma-Aldrich, 99\%) and biodiesel (JSC "Mestila") were investigated. The blends were coded to unify the name: $\mathrm{M}$-methanol, \% (volume basis); and B-biodiesel \% (volume basis). Two diesel-biodiesel blends were produced: $\mathrm{B} 6.8 \mathrm{M} 0$, which contains $6.8 \%$ biodiesel in the base blend of diesel and additives, and B10M0, which contains $10 \%$ biodiesel in the base blend. The letter M indicates the quantity of biomethanol in the mixture, which varies from 0 to $30 \%$ (volume basis). Dodecanol and 2-ethylhexyl nitrate were used as dispersive additives. Each parameter was replicated 5 times, and standard deviation values were calculated.

The physical properties of each mixture, namely density, kinematic viscosity, cetane index, flash point, cloud point, the calorific value, and the boiling behavior, were investigated according to the standards for estimation listed in Table 1. Table 1 also gives values of properties of a marine diesel oil for comparison to the standard ISO 8217:2017 (DMB grade).

In order to determine similar groups of mixtures of biodiesel and diesel according to the six different physical properties of the mixtures, an indirect multivariate analysis was performed [29]. The number of similarity groups were evaluated by a hierarchical cluster analysis based on Euclidean distance with the vegan package [30]. Additionally, the optimal number of clusters was determined via a K-means cluster analysis using the factoextra package [31]. Using the vegan package, a permutational multivariate variance analysis using distance matrices (ADONIS) was performed to determine the differences in the clusters. For each physical property of the mixtures, all pairwise comparisons of the mean values between delineated clusters were performed using the Games-Howell test with the PMCMRplus package [32]. 
Table 1. Comparison of the physical properties of biomethanol, biodiesel and diesel and their standards of determination with the requirements for marine fuel of the ISO 8217:2017 standard.

\begin{tabular}{|c|c|c|c|c|c|}
\hline \multirow{2}{*}{ Parameter } & \multirow{2}{*}{$\begin{array}{l}\text { Standards for } \\
\text { Estimation of the } \\
\text { Parameters }\end{array}$} & \multirow{2}{*}{$\begin{array}{l}\text { ISO 8217:2017 } \\
\text { Limits } \\
\text { (DMB Grade) }\end{array}$} & \multicolumn{3}{|c|}{ Measured Values for the Blend Components } \\
\hline & & & Diesel & Biodiesel & Methanol \\
\hline $\begin{array}{l}\text { Density at } 15^{\circ} \mathrm{C}, \\
\mathrm{kg} \mathrm{m}^{-3}\end{array}$ & EN ISO 3675:1999 & Max 900 & $843 \pm 0.01$ & $877 \pm 0.01$ & $797 \pm 0.01$ \\
\hline \multirow{2}{*}{$\begin{array}{l}\text { Kinematic viscosity } \\
\text { at } 40^{\circ} \mathrm{C}, \mathrm{mm}^{2} \mathrm{~s}^{-1}\end{array}$} & \multirow{2}{*}{ EN ISO 3104:1994 } & Min 2.00 & \multirow{2}{*}{$2.80 \pm 0.01$} & \multirow{2}{*}{$4.30 \pm 0.01$} & \multirow{2}{*}{$1.01 \pm 0.01$} \\
\hline & & Max 11.00 & & & \\
\hline \multirow{2}{*}{ Distillation } & \multirow{2}{*}{ ASTM D86-20 } & \multirow{2}{*}{ - } & $250{ }^{\circ} \mathrm{C}-33 \%$ & \multirow{2}{*}{ - } & \multirow{2}{*}{ - } \\
\hline & & & $350^{\circ} \mathrm{C}-95 \%$ & & \\
\hline $\begin{array}{l}\text { Calculated cetane } \\
\text { index }\end{array}$ & ASTM D976-06(16) & Min 35 & 51 & 50 & 5 \\
\hline Flash point, ${ }^{\circ} \mathrm{C}$ & EN ISO 2719:2016 & Min 60 & 62 & $120 \pm 1$ & $11 \pm 1$ \\
\hline Cloud point, ${ }^{\circ} \mathrm{C}$ & EN 3015:2019 & - & Minus $19 \pm 1$ & Minus $12 \pm 1$ & Minus $98 \pm 1$ \\
\hline $\begin{array}{l}\text { Gross calorific value, } \\
\mathrm{MJ} \mathrm{kg}^{-1}\end{array}$ & DIN 51900-3:2003 & - & - & $40 \pm 0.01$ & $23 \pm 0.01$ \\
\hline
\end{tabular}

\section{Results and Discussion}

As this study dealt with the dependencies of the physical properties of a fuel based on biodiesel and methanol that could be used as a substitute for conventional MDOs according to ISO, the influence of the additives had to be kept as low as possible. Therefore, the minimum quantity of dodecanol and 2-ethylhexyl nitrate as dispersing additives for stabilizing a mixture of $0.25 \mathrm{vol}-\%$ methanol in diesel was first examined. Contrary to the literature $[23,24]$, which states the addition of $10 \%$ alcohol like dodecanol and up to $1 \%$ nitric acid ester like 2-ethylhexylnitrate for a homogeneous mixture, in this work, only $1 \%$ dodecanol and $0.5 \%$ 2-ethylhexylnitrate were sufficient. Due to the very small quantities, it could be assumed that the negative effects on the cetane index and the calorific value according to [23] were negligible. This assumption was confirmed in the following presentation of results by the methanol-free diesel-biodiesel mixtures with and without additives.

Results of the density test of methanol-biodiesel-diesel blends: The study showed that an increase in the biodiesel content of the blend slightly increased the density, but methanol decreased the density by $1 \%$ for diesel-biodiesel blends with $6.8 \%$ (volume basis) biodiesel and by $1.5 \%$ for blends with $10 \%$ (volume basis) biodiesel (Figure 1). The additives increased the density by less than $0.2 \%$.

It was found that all 20 blends complied with the maximum limit of $900 \mathrm{~kg} \mathrm{~m}^{-3}$ defined in ISO 8217:2017 (DMB grade). Similar results were observed in [24,33-35] - the presence of methanol in the mixtures reduced their density.

Results of testing the kinematic viscosity of methanol-biodiesel-diesel mixtures: As can be seen in Table 1, the kinematic viscosity of biodiesel is $4.3 \mathrm{~mm}^{2} \mathrm{~s}^{-1}$, which leads to an increase in kinematic viscosity of mixtures.

Unlike density, the influence of methanol on the kinematic viscosity of diesel-biodiesel blends was greater: When the methanol content of the B6.8 blends was increased from 5 to $30 \%$ (volume basis), the decrease in kinematic viscosity (from 2.81 to $2.05 \mathrm{~mm}^{2} \mathrm{~s}^{-1}$ ) was $27 \%$ compared to diesel and $31 \%$ compared to the B6.8M0 blend (Figure 2). Meanwhile, with the same increase in the methanol content of the B10 mixtures, the kinematic viscosity decreased from 2.94 to $2.48 \mathrm{~mm}^{2} \mathrm{~s}^{-1}$ by $11 \%$ compared to diesel and $22 \%$ compared to the B10M0 mixture. The lowest kinematic viscosity was found in the B6.8M30 blend. It reached $2.05 \mathrm{~mm}^{2} \mathrm{~s}^{-1}$, which was very close to the minimum permissible limit of $2.00 \mathrm{~mm}^{2} \mathrm{~s}^{-1}$, so it was very important to monitor the viscosity when the composition of the blend was changed. 


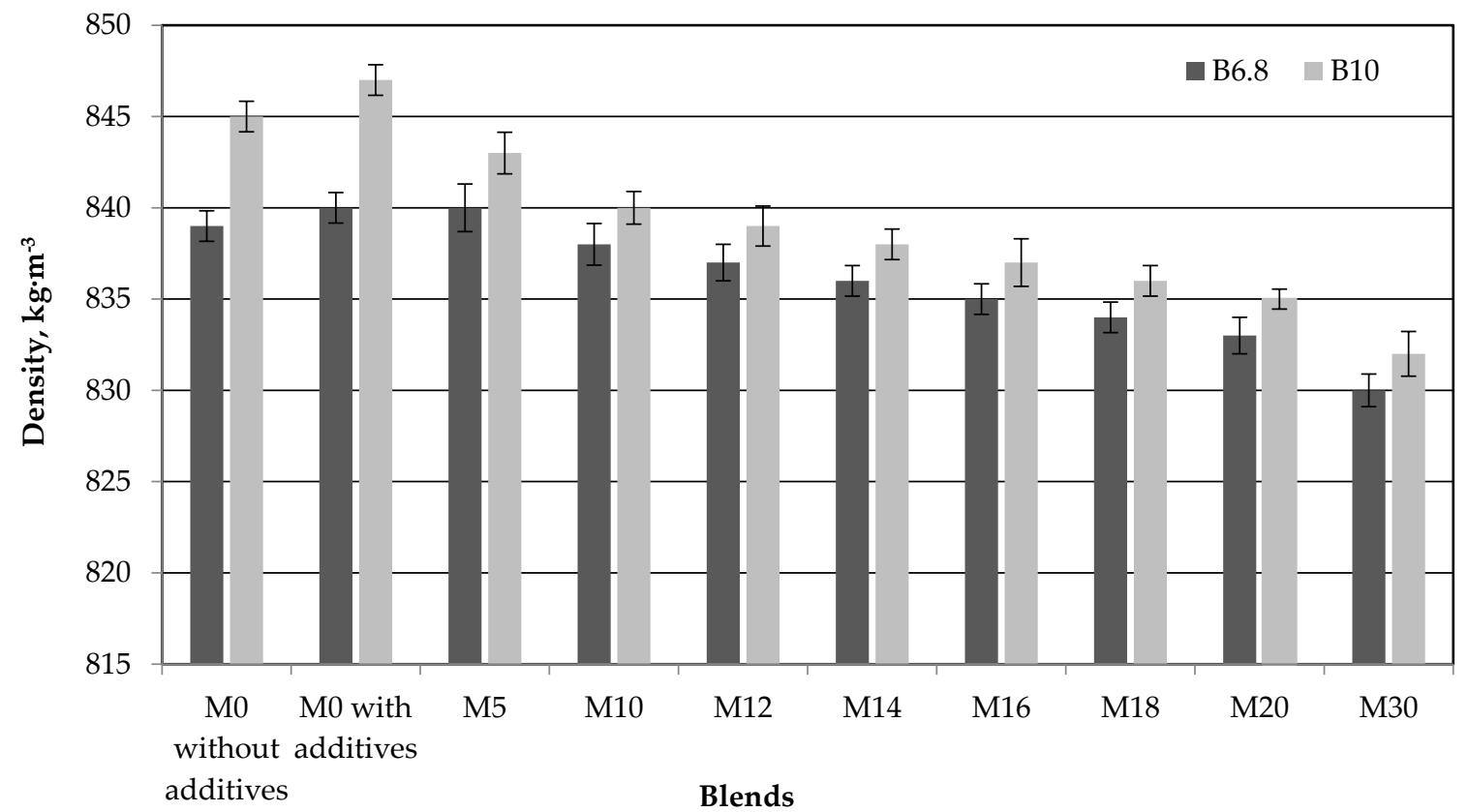

Figure 1. Results of the density test of the two diesel-biodiesel blends (B6.8 and B10; B: biodiesel percentage) as a function of methanol content (where $\mathrm{M}$ is the methanol percentage; $\mathrm{M} 0=0 \%$ to $\mathrm{M} 30=30 \%$ methanol). Error bars show the standard deviation.

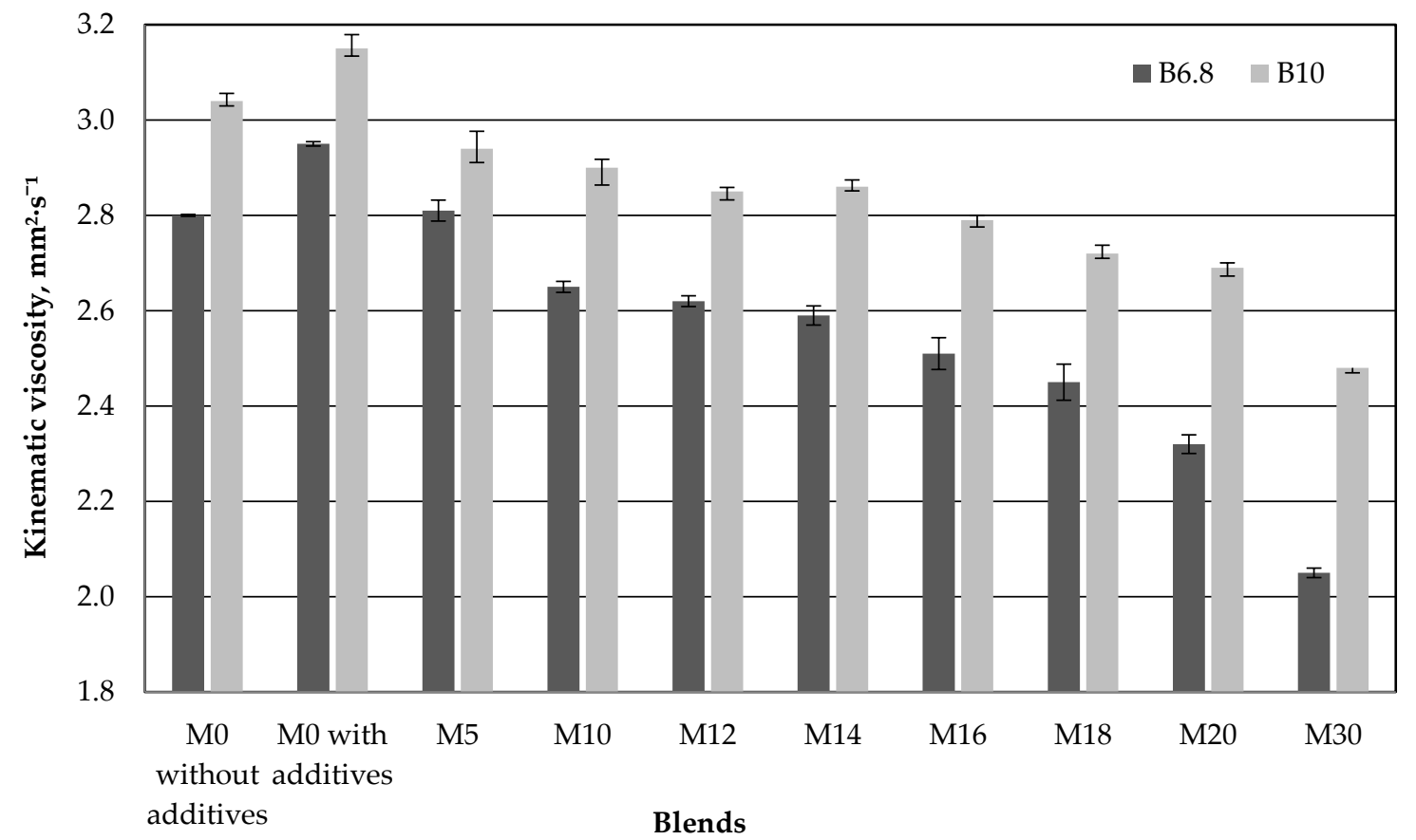

Figure 2. Results of the test of the kinematic viscosity of the two diesel-biodiesel blends (B6.8 and B10) as a function of methanol content. Error bars show the standard deviation.

It was found that all 20 blends complied with the limits set by the ISO 8217:2017 standard (DMB grade). A study of [35] showed that the viscosity of biodiesel can be reduced by adding alcohol, although it should be noted that [35] and [18] derived their conclusions on the basis of a greatly reduced number of low-variety blends.

Results of testing the gross calorific value of methanol-biodiesel-diesel blends: The calorific value is not regulated in the marine fuel standard ISO 8217:2017 (DMB grade), but it is an important 
parameter for assessing the amount of heat that can be released during the combustion of different blends and for determining changes in fuel consumption.

During the analysis of the gross calorific values of blends, it was found that B10M0 (blend without additives) had a maximum calorific value of $45.358 \mathrm{MJ} \mathrm{kg}^{-1}$ (Figure 3). The addition of fuel additives reduced the gross calorific value by $0.27 \%$ to $45.028 \mathrm{MJ} \mathrm{kg}^{-1}$. Similar to the previous properties, increasing the methanol content from 5 to $30 \%$ (volume basis) in blends with additives resulted in a decrease in calorific value.

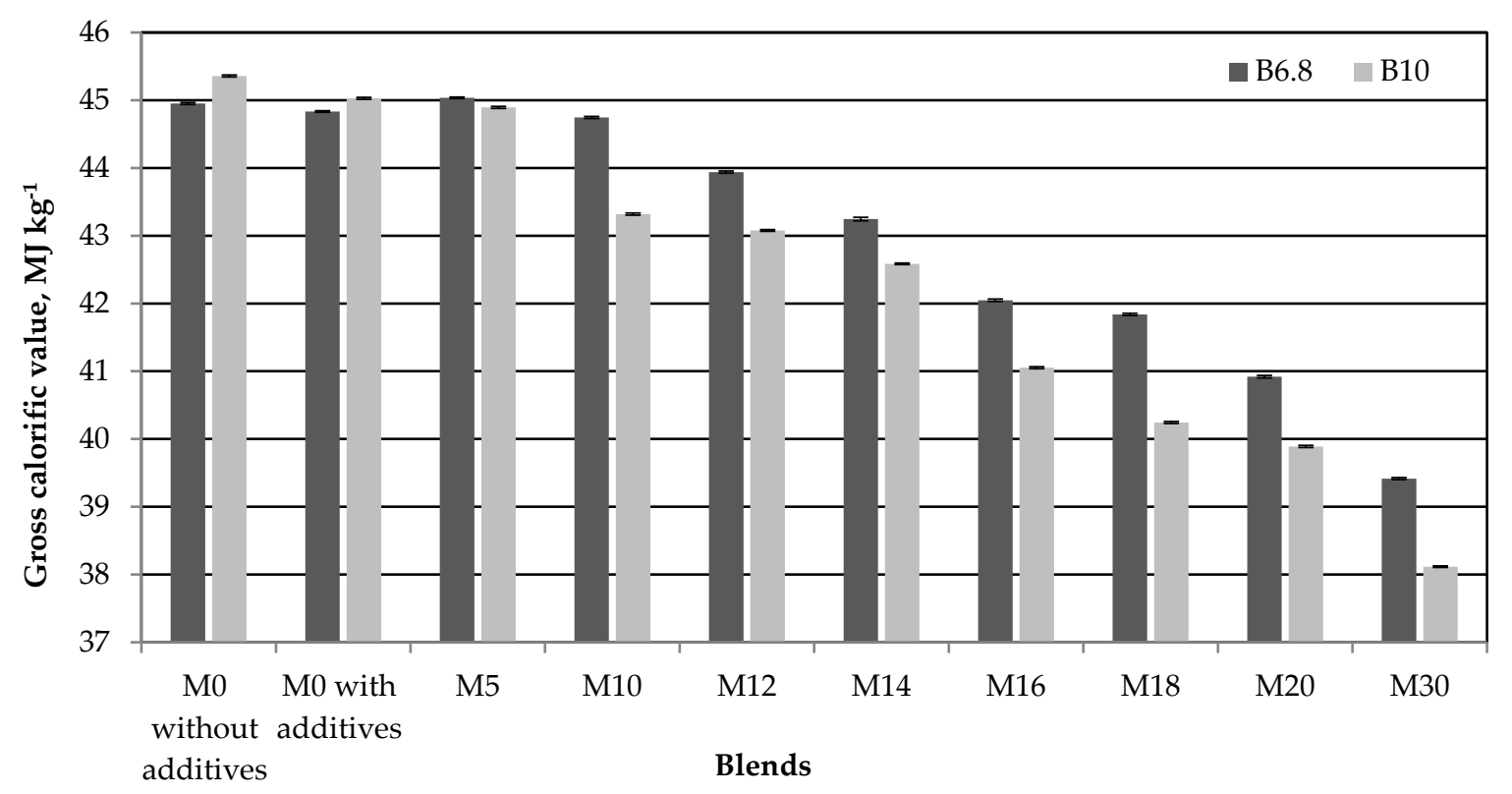

Figure 3. Results of the test of the gross calorific value of the two diesel-biodiesel mixtures (B6.8 and B10) as a function of methanol content. Error bars show the standard deviation.

A similar trend has been reported in reviews $[8,19]$.

Results of the flash point test of methanol-biodiesel-diesel blends: Due to the low flash point of methanol (Table 1), it could be expected that an increase in the methanol content in the blends would have lowered their flash point, but the addition of biodiesel could compensate for the value of this parameter. A compensation by the comparatively high flash points of the additives was almost impossible due to their low content in the blends.

The flash point of the B6.8M0 blend reached an increase of $1.4-64.6^{\circ} \mathrm{C}$ with the addition of dodecanol and 2-ethylhexyl nitrate (Figure 4). A similar tendency was observed in the B10M0 blends with additives when the flash point in each case increased from 62.1 to $67.6^{\circ} \mathrm{C}$. However, the flash point of the B6.8M5, B10M5, and B10M10 mixtures dropped from 20 to 40,41 , and $40{ }^{\circ} \mathrm{C}$, respectively.

A further increase of the methanol content to $12 \%$ (volume basis) resulted in a further reduction to about $20^{\circ} \mathrm{C}$. However, each further increase of the methanol content up to $30 \%$ (volume basis) then remained constant at about $20^{\circ} \mathrm{C}$ for both base mixtures (B6.8Mx and $\left.\mathrm{B} 10 \mathrm{Mx}\right)$.

The authors of [18] investigated in their scientific work M5- and M10-mixtures, and in their work, the flashpoints reached 45 and $49^{\circ} \mathrm{C}$, respectively.

Results of the test of the cloud point of methanol-biodiesel-diesel mixtures: The highest cloud point was found for $\mathrm{B} 6.8 \mathrm{M} 0$, which was 2.5 times higher than for the $\mathrm{B} 6.8 \mathrm{M} 30$ mixture, where the methanol content increased from 0 to $30 \%$ (volume basis). The addition of dodecanol and 2-ethylhexyl nitrate additives to the mixtures showed no change in the cloud point temperature of the mixtures and had only minimal effects on the variation of this parameter. 


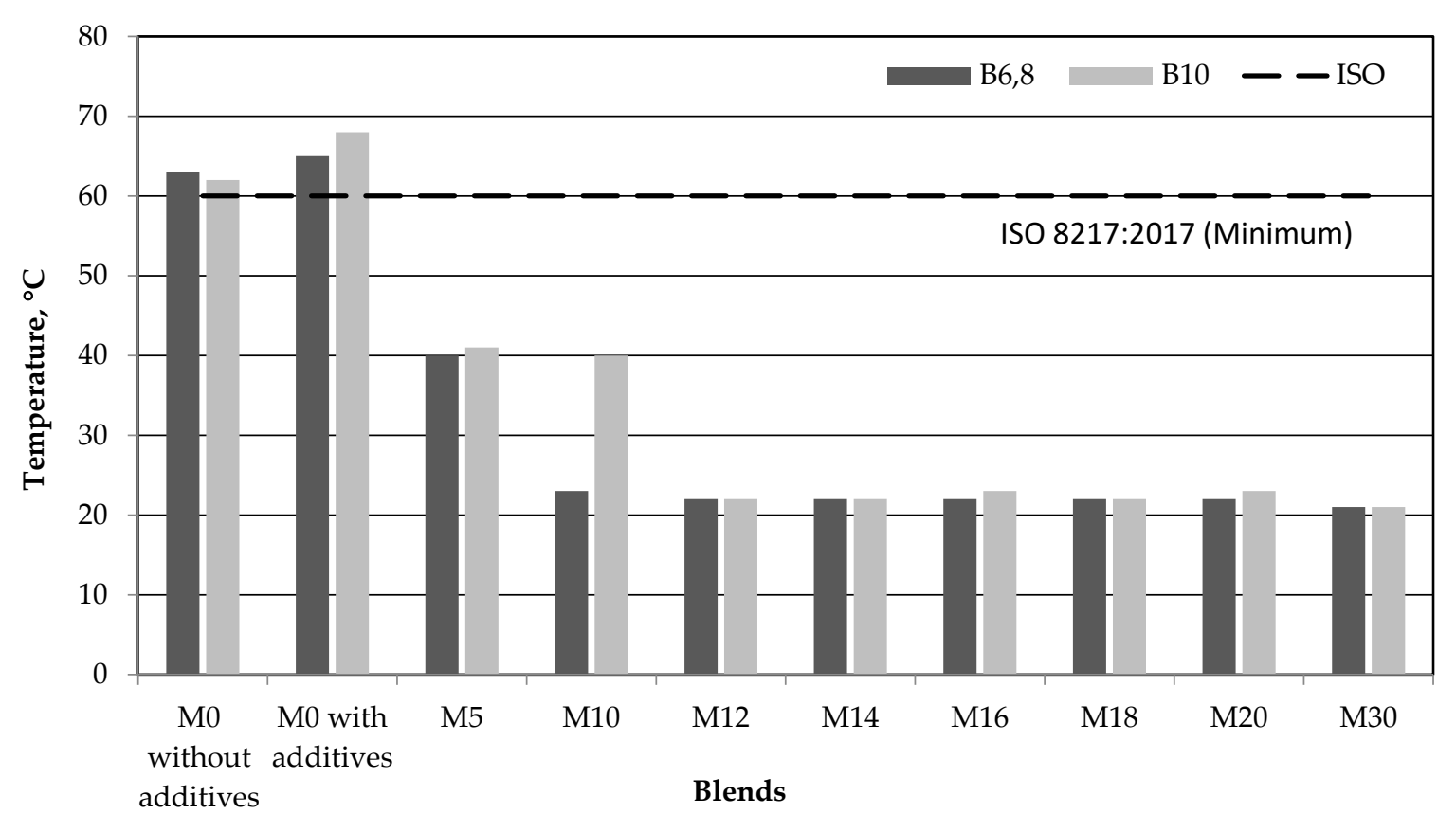

Figure 4. Results of the test of the flash point of the two diesel-biodiesel mixtures (B6.8 and B10) as a function of methanol content.

It was found that the addition of 5\% (volume basis) methanol to the B6.8 mixtures reduced their cloud point temperature by a factor of three (from -4 to $-12{ }^{\circ} \mathrm{C}$ ), while in the case of the B10 mixtures, it decreased by a factor of 3.3 (from -3 to $-10^{\circ} \mathrm{C}$ ). As the methanol content of the mixtures increased from 5 to $18 \%$ (volume basis), the temperature of the $\mathrm{B} 6.8$ mixture dropped to as low as $-14{ }^{\circ} \mathrm{C}$ and that of the B10 mixture to as low as $-16^{\circ} \mathrm{C}$. As can be seen in Figure 5, the mixtures reached a minimum of the cloud point at methanol contents of $12-18 \%$. A further increase of the methanol content to up to $30 \%$ (volume basis) caused the cloud point temperature to rise again in both base mixtures. To the authors' knowledge, such a behavior has not been described in the studies of the properties of diesel and/or biodiesel and alcohol mixtures concerning the cloud point $[19,36]$.

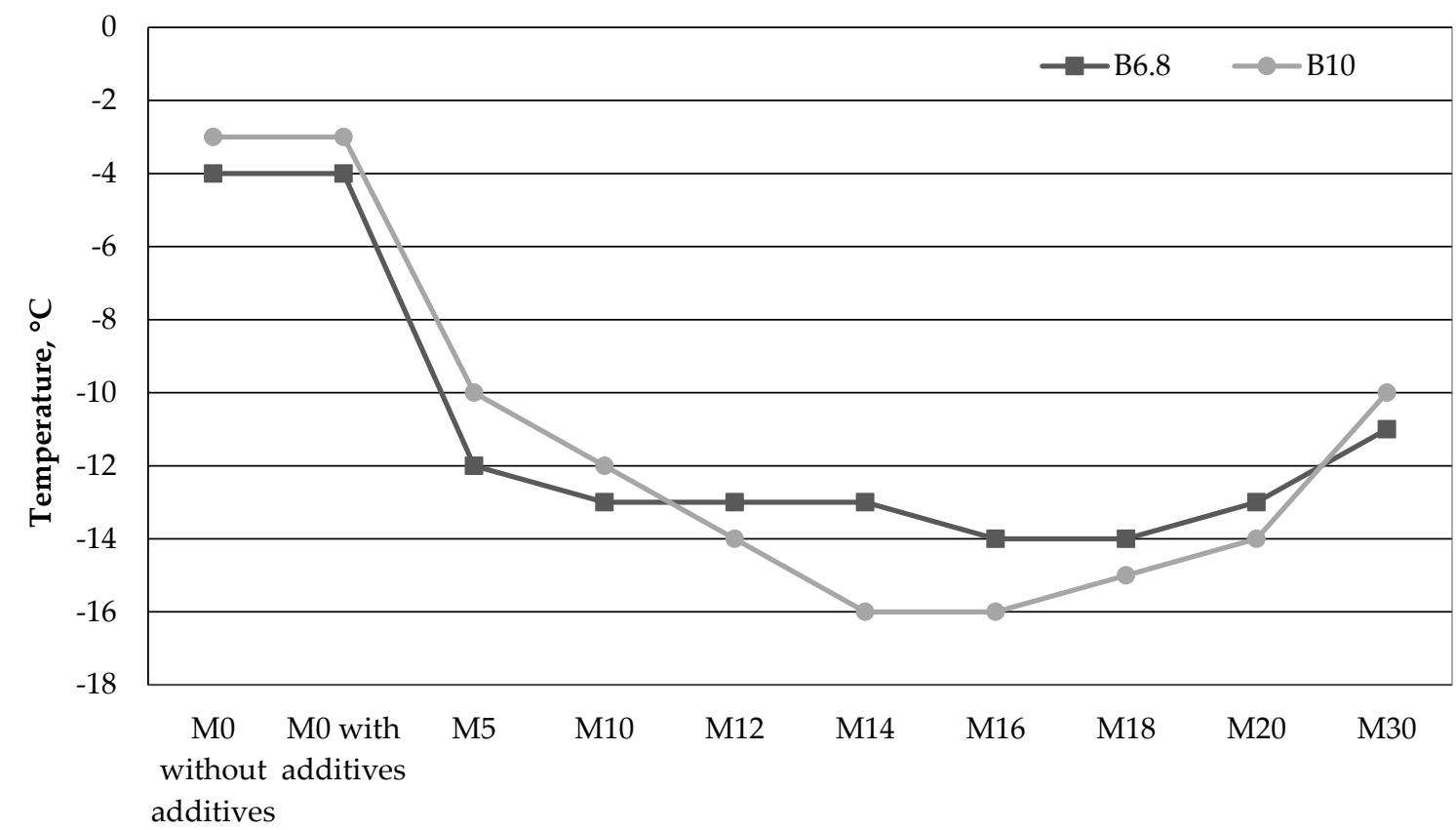

Figure 5. Results of the test of the cloud point of the two diesel-biodiesel mixtures $(\mathbf{\square} 6.8$ and $\bullet$ B10) as a function of methanol content. 
The authors of [37] reported that one of the disadvantages of biodiesel is its high cloud point compared to diesel. This disadvantage can be compensated for by methanol, as described above.

Results of testing the distillation of methanol-biodiesel-diesel mixtures: Figure 6A,B show that methanol-free mixtures had higher boiling points. The first drop showed the temperature at which the mixture began to boil, which depended on the composition of the mixture. If the mixtures contained more than $10 \%$ (volume basis) methanol, they started boiling at $61{ }^{\circ} \mathrm{C}$. In addition, the first drop of B6.8M0 mixtures with and without additives fell at 124 and $135^{\circ} \mathrm{C}$, respectively, (Figure 6A), and in the B10M0 mixtures with and without additives, it fell at 115 and $123^{\circ} \mathrm{C}$, respectively (Figure 6B). It was observed that when the biodiesel content was increased from 6.8 to $10 \%$ (volume basis), the boiling point of the blends dropped by $9 \%$ from 135 to $123{ }^{\circ} \mathrm{C}$.
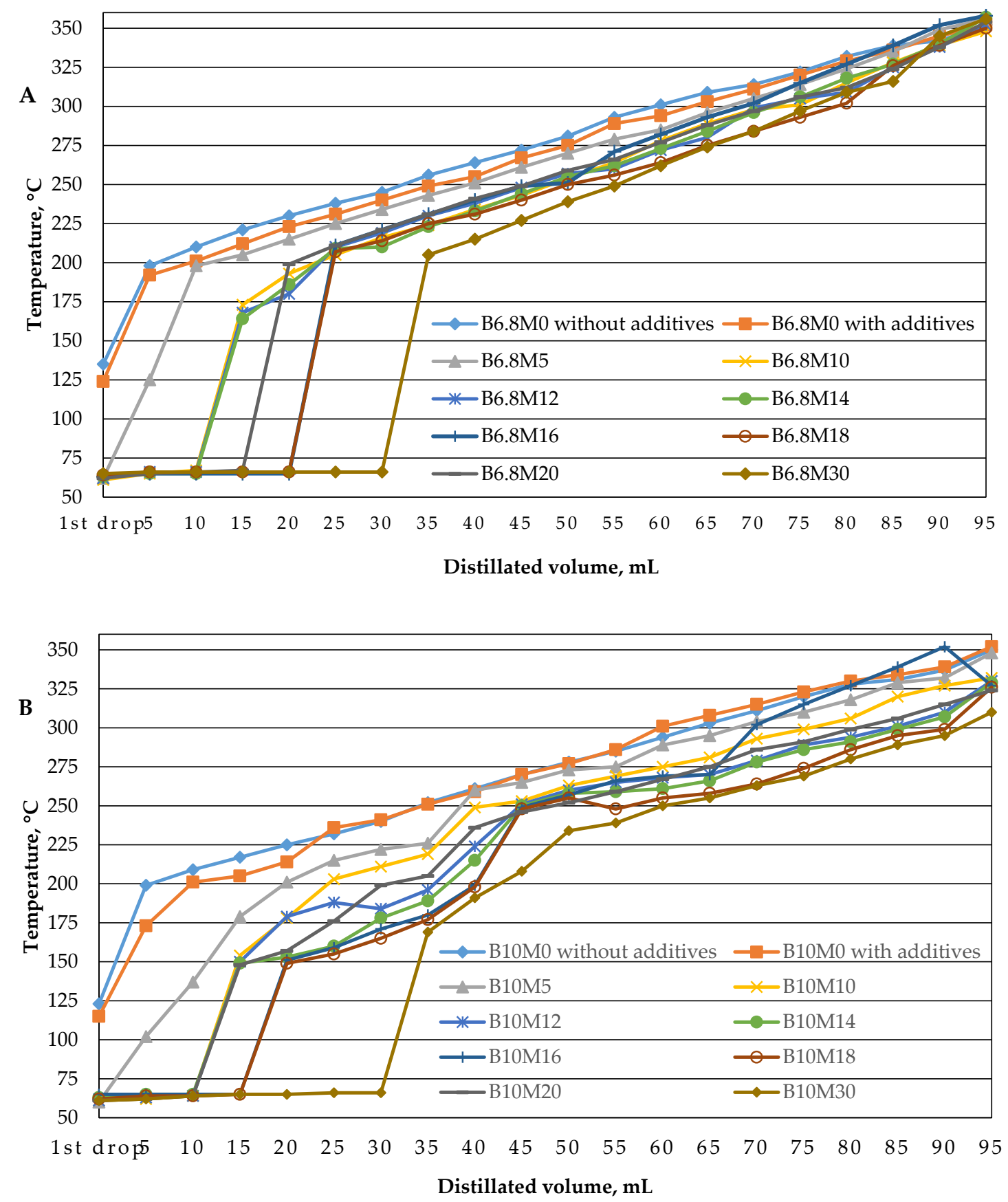

Figure 6. Results of testing the distillation of methanol-biodiesel-diesel mixtures: (A)-biodiesel content in blends: $6.8 \%$ (volume basis); (B) - biodiesel content in blends: $10 \%$ (volume basis). 
As can be seen from the figures, the boiling point of the methanol-containing blends containing more than $10 \%$ methanol abruptly increased at about the volume of the distillate corresponding to the respective methanol content of the blend. However, the boiling temperature always remained below the corresponding boiling temperature of the pure base mixture of diesel-biodiesel and the additives, even with higher methanol contents contained in the initial mixture. Only when about $90 \%$ of the mixture was distilled off did the boiling temperatures coincide, at least for the B6.8Mx mixtures (Figure 6A). In both base mixtures, the boiling temperature steadily increased in the BxM5 mixtures. They did not remain at about $61^{\circ} \mathrm{C}$ until $5 \mathrm{~mL}$ of liquid was distilled off. In any case, a residual amount of $1.6-1.9 \%$ (volume basis) remained in the source material.

Results of the calculated cetane index of methanol-biodiesel-diesel mixtures: According to the standard ISO 8217:2017 (DMB grade), marine diesel oil must have a cetane index of at least 35, which is up to seven times higher than methanol, which has an extremely low cetane index of 5 . Biodiesel has a cetane index of 50 .

The highest cetane indexes were found in non-methanol blends with $6.8 \%$ (volume basis) biodiesel (cetane index: 54) and 10\% (volume basis) biodiesel (cetane index: 51) (Figure 7). With a methanol content of the blend of 30\% (volume basis), the cetane index of B6.8 and B10 blends fell by $13 \%$ to 47 and 45 , respectively.

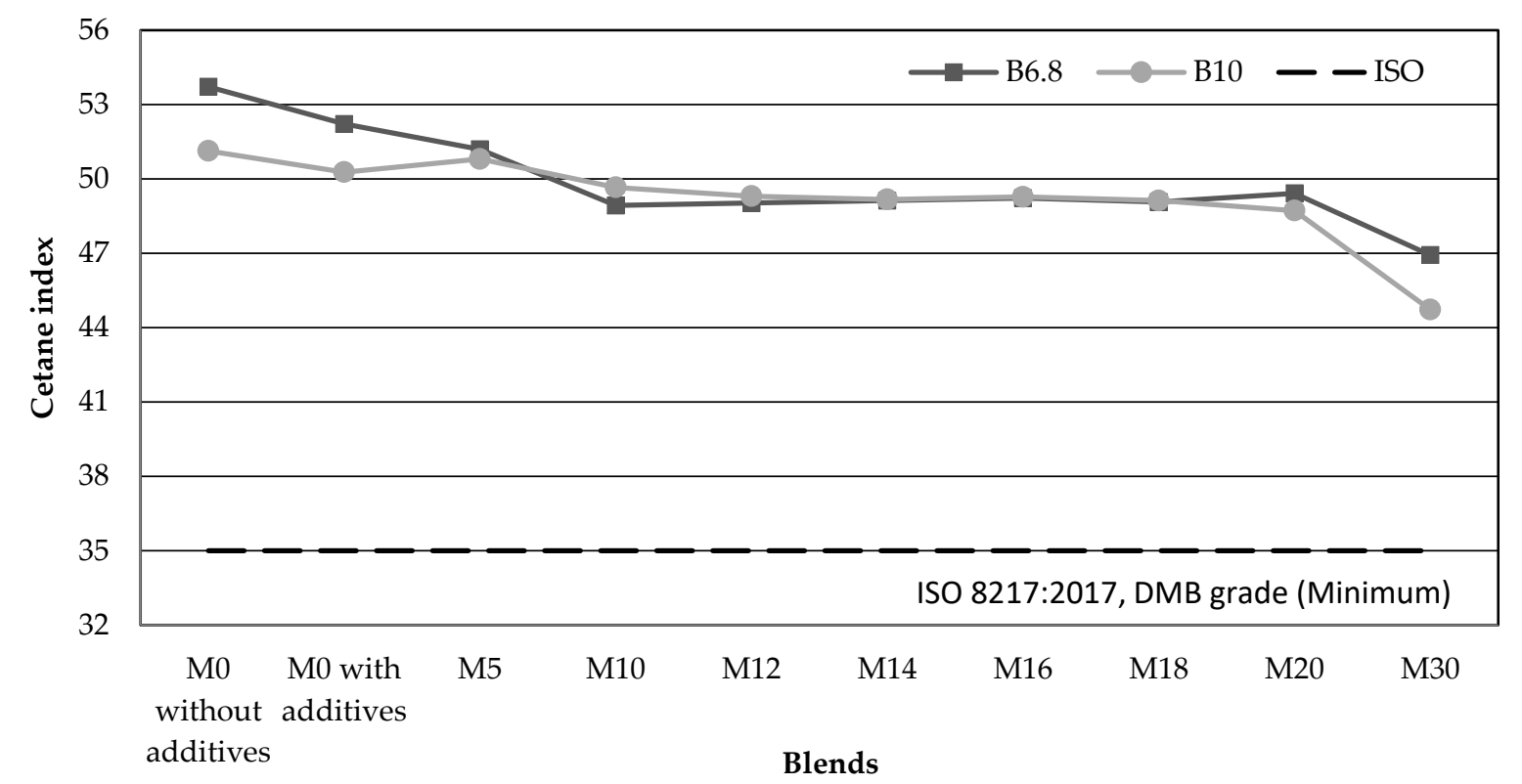

Figure 7. Results of the calculated cetane index of the two diesel-biodiesel blends (B6.8 and B10) as a function of methanol content.

In the studies [16,34], it was observed that the B20M0 blend has a 17\% lower cetane index (44) compared to marine diesel oil. According to ISO 8217: 2017 (DMB grade), the marine cetane index should reach 35 . All blends tested in the study met the minimum cetane index value according to the standard.

Results of the multivariate analysis: In the cluster analysis, three significant $(\mathrm{F}=332.05 ; \mathrm{df}=1$; $p=0.001$ ) groups were determined (Figure 8 ), the first one mainly consisting of mixtures without methanol. In the second cluster, the mixtures with methanol concentrations of 5\% (B6.8M5 and B10M5) and a mixture with 10\% (B10M10) dominated, and the third cluster consisted of all remaining mixtures. 

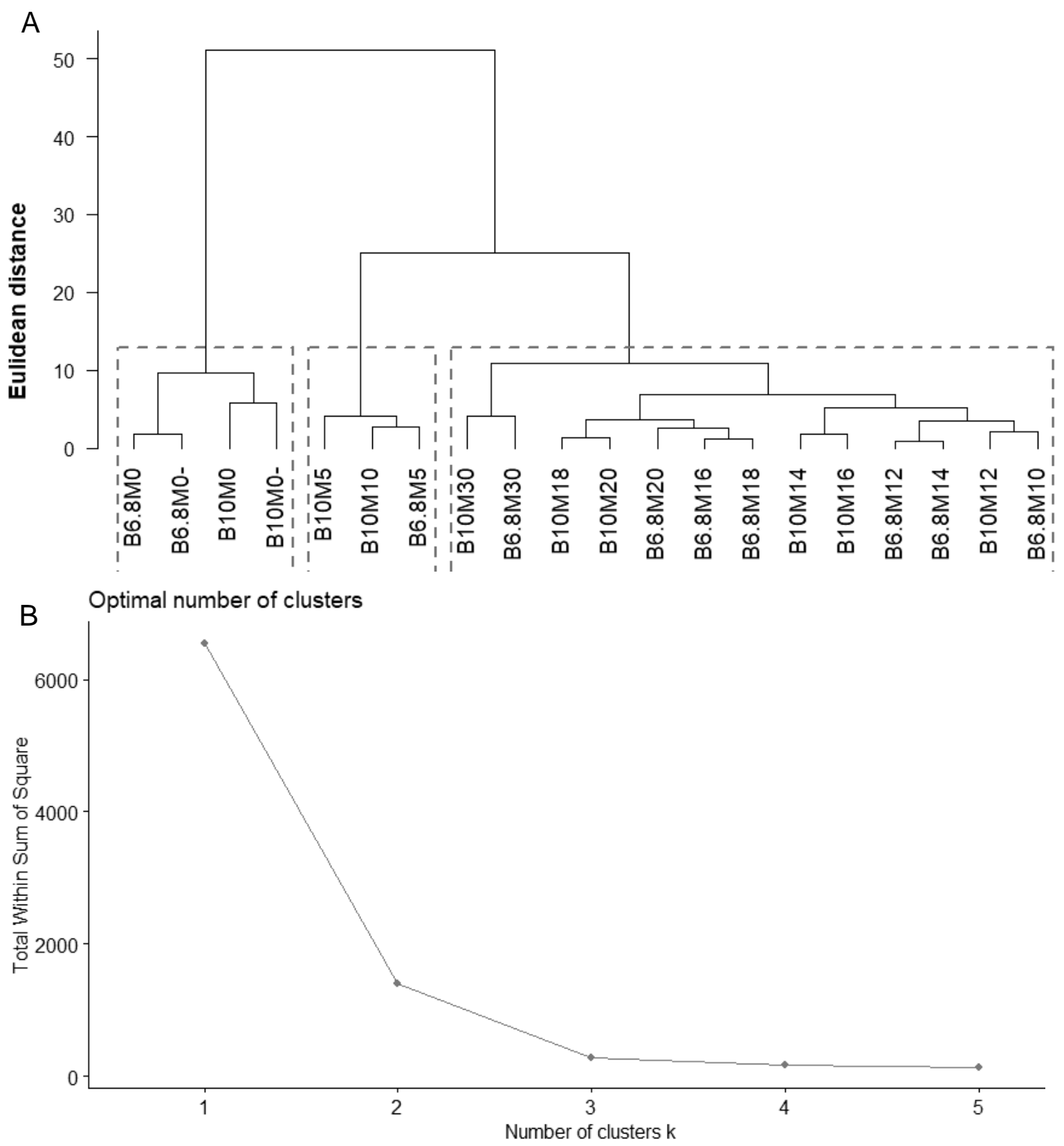

Figure 8. The hierarchical cluster dendrogram (A) grouping different blends based on the dissimilarity coefficient (Euclidean distance) and the number of optimal clusters by means of the K-means cluster analysis (B). The location of a bend in the function of the total within-cluster sum of square indicates the optimal number of clusters (3), i.e., hereafter the function remains minimal. Three clusters indicated in the dendrogram by dotted line. M0: with additives; M0-: without additives.

Among the physical properties of the mixtures, flash point was the most discriminated variable (Figure 9), with the mean values differed significantly $(p<0.001)$ between the specific clusters (i.e., the highest mean value was in the first cluster and the lowest mean value was in the third). Similarly, the means of cloud point significantly $(p<0.05)$ differed between the clusters. The mean of density in the second cluster was significantly $(p<0.05)$ higher than the mean in the third cluster, whereas the mean in the first cluster did not significantly differ from both clusters. The mean of cetane number in the first cluster was significantly $(p<0.05)$ higher than the mean in the third cluster, whereas the mean in the second cluster did not significantly differ from both clusters. The means 
of viscosity and calorific value did not significantly differ between the first and the second clusters, but they were significantly $(p<0.05)$ higher than in the third cluster.
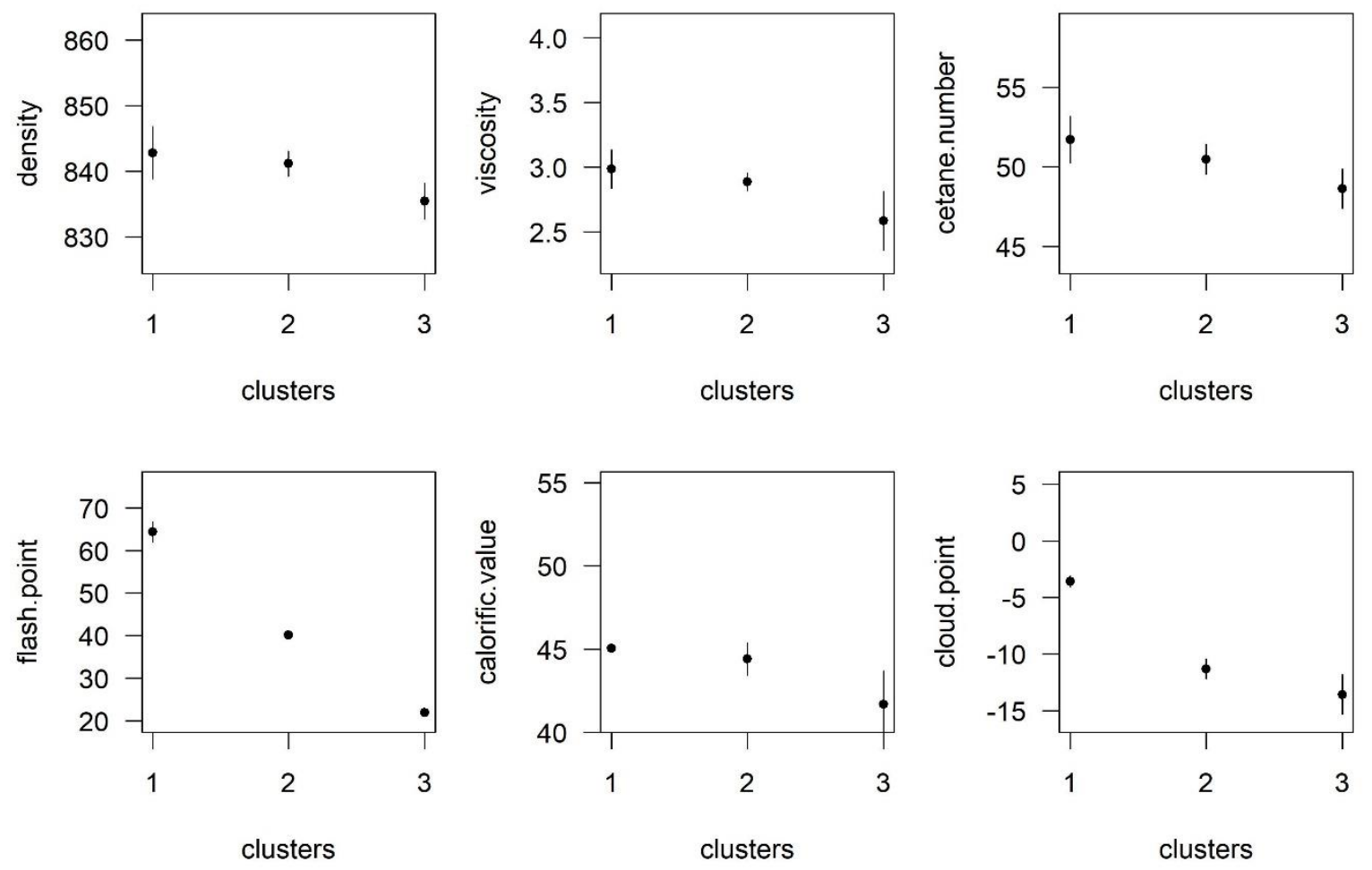

Figure 9. The mean ( \pm standard deviation) values of the different physical properties of mixtures in the three clusters.

Figure 9 shows that the mixtures with low methanol content were very close to the methanol-free mixtures of diesel and biodiesel in terms of density, kinematic viscosity, cetane index and calorific value. It can therefore be concluded that a low methanol blend behaves like a diesel/biodiesel fuel and would not require any further adjustment if it were used as a fuel instead of a methanol-free blend. There was clear improvement in low methanol blends in relation to the cloud point, where a significant reduction could be observed due to the addition of methanol (as shown by cluster group 3). A small amount of 5 or $10 \%$ methanol was sufficient to lower the cloud point. Similarly, the flashpoint was lowered significantly by adding a small amount of methanol. The ISO 8217:2017 standard stipulates a minimum of $60^{\circ} \mathrm{C}$.

\section{Conclusions}

Diesel-biodiesel blends with additives (1\% (volume basis) dodecanol and $0.5 \%$ (volume basis) 2-ethylhexyl nitrate) and a low methanol content of about $5 \%$ (volume basis) seem to be the most suitable for use as marine diesel fuel according to the ISO 8217:2017 standard (DMB grade). The density, kinematic viscosity, calorific value and cetane index of this mixture are very similar to pure diesel or diesel-biodiesel blends. A clear advantage of the B6.8M5 and B10M5 mixtures compared to diesel-biodiesel blends is their significantly lower cloud point. However, an improvement has to be made with regard to the flash point, which is the subject of ongoing research activities.

Finally, this means that $5 \%$ of the mineral diesel could be replaced by (bio-)methanol if the flashpoint could be adjusted. 
Author Contributions: Conceptualization, T.P.; methodology, T.P., J.U. and M.B.; software, M.B.; validation, T.P., J.U. and M.B.; formal analysis, T.P. and J.U.; investigation, T.P. and Z.W.; resources, J.U.; data curation, T.P. and M.B.; writing — original draft preparation, T.P. and Z.W.; writing—review and editing, J.U. and Z.W.; visualization, T.P., J.U. and M.B.; supervision, T.P.; project administration, T.P.; funding acquisition, T.P. and Z.W. All authors have read and agreed to the published version of the manuscript.

Funding: This research was funded by Shanghai Government Science and Technology commission, grant number 17170712100.

Conflicts of Interest: The authors declare no conflict of interest.

\section{Abbreviations}

$\begin{array}{ll}\text { Abbreviations } & \text { Meaning } \\ \text { IMO } & \text { International Maritime Organization } \\ \text { MDO } & \text { Marine diesel oil } \\ \text { M } & \text { Methanol } \\ \text { B } & \text { Biodiesel } \\ \text { B6.8 } & \text { Blend that contains } 6.8 \% \text { biodiesel (volume basis) } \\ \text { B10 } & \text { Blend that contains } 10 \% \text { biodiesel (volume basis) }\end{array}$

\section{References}

1. Svanberg, M.; Ellis, J.; Lundgren, J.; Landval, I. Renewable methanol as a fuel for the shipping industry. Renew. Sustain. Energy Rev. 2018, 94, 1217-1228. [CrossRef]

2. Sahin, B.; Yilmaz, H.; Ust, Y.; Fuat Guneri, A.; Gulsun, B.; Turan, E. An Approach for Economic Analysis of Intermodal Transportation. Sci. World J. 2014, 630320. [CrossRef]

3. Bialystocki, N.; Konovessis, D. On the estimation of ship's fuel consumption and speed curve: A statistical approach. J. Ocean Eng. Sci. 2016, 1, 157-166. [CrossRef]

4. Mohd Noor, C.W.; Noor, M.M.; Mamat, R. Biodiesel as alternative fuel for marine diesel engine applications: A review. Renew. Sustain. Energy Rev. 2018, 94, 127-142. [CrossRef]

5. World Health Organization. Air Pollution. Available online: https://www.who.int/health-topics/airpollution\#tab=tab_1 (accessed on 14 August 2020).

6. Zhang, Q.; Jiang, X.; Tong, D.; Davis, S.J.; Zhao, H.; Geng, G.; Feng, T.; Zheng, B.; Lu, Z.; Streets, D.G.; et al. Transboundary health impacts of transported global air pollution and international trade. Nature 2017, 543, 705-709. [CrossRef] [PubMed]

7. Zannis, T.C.; Yfantis, E.A.; Pagagiannakis, R.; Levendis, Y. Chapter 1: Critical Review of Conventional Fuel Composition and Properties on Diesel Engine Performance and Pollutant Emissions. In Diesel Fuels: Characteristics, Performance and Environmental Impacts; Silva, C., Rivera, A., Eds.; Nova Science Publishers: New York, NY, USA, 2013.

8. Erdiwansyah, M.R.; Sani, M.S.; Sudhakar, K.; Sardjono, R.E. An overview of Higher alcohol and biodiesel as alternative fuels in engines. Energy Rep. 2019, 5, 467-479. [CrossRef]

9. Kumar Agarwal, A. Biofuels (alcohols and biodiesel) applications as fuels for internal combustion engines. Prog. Energy Combust. Sci. 2007, 33, 233-271. [CrossRef]

10. Bušić, A.; Marđetko, N.; Kundas, S.; Morzak, G.; Belskaya, H.; Ivančić Šantek, M.; Komes, D.; Novak, S.; Šantek, B. Bioethanol Production from Renewable Raw Materials and Its Separation and Purification: A Review. Food Technol. Biotechnol. 2018, 56, 289-311. [CrossRef]

11. Kalligeros, S.; Zannikos, F.; Stournas, S.; Lois, E.; Anastopoulos, G.; Teas, C.; Sakellaropoulos, F. An investigation of using biodiesel/marine diesel blends on the performance of a stationary diesel engine. Biomass Bioenergy 2003, 24, 141-149. [CrossRef]

12. Morone, P.; Strzalkowski, A.; Tani, A. Chapter 2-Biofuel transitions: An overview of regulations and standards for a more sustainable framework. In Biofuels for a More Sustainable Future-Life Cycle Sustainability Assessment and Multi-Criteria Decision Making; Ren, J., Scipioini, A., Manzardo, A., Liang, H., Eds.; Elsevier Inc.: Amsterdam, The Netherlands, 2020; pp. 21-46. [CrossRef] 
13. Mishra, V.K.; Goswami, R. A review of production properties and advantages of biodiesel. Biofuels 2018, 9, 273-289. [CrossRef]

14. Pollitt, K.J.G.; Chhan, D.; Rais, K.; Pan, K.; Wallace, J.S. Biodiesel fuels: A greener diesel? A review from a health perspective. Sci. Total Environ. 2019, 688, 1036-1055. [CrossRef] [PubMed]

15. Bos, M.J.; Kersten, S.R.A.; Brilman, D.W.F. Wind power to methanol: Renewable methanol production using electricity, electrolysis of water and CO2 air capture. Appl. Energy 2020, 264, 114672. [CrossRef]

16. Shamsul, N.S.; Kamarudin, S.K.; Rahman, N.A.; Kofli, N.T. An overview on the production of bio-methanol as potential renewable energy. Renew. Sustain. Energy Rev. 2014, 33, 578-588. [CrossRef]

17. Hajba, L.; Eller, Z.; Nagy, E.; Hancsok, J. Properties of diesel-alcohol blends. Hung. J. Ind. Chem. 2011, 39, 349-352.

18. Yasin, M.H.; Mamat, R.; Aziza, A.; Najafi, G. Comparative Study on Biodiesel-methanol-diesel Low Proportion Blends Operating with a Diesel Engine. Energy Procedia 2015, 75, 10-16. [CrossRef]

19. Niculescu, R.; Clenci, A.; Iorga-Siman, V. Review on the Use of Diesel-Biodiesel-Alcohol Blends in Compression Ignition Engines. Energies 2019, 12, 1194. [CrossRef]

20. Lapuerta, M.; Armas, O.; Garcia-Contreras, R. Stability of diesel-bioethanol blends for use in diesel engines. Fuel 2007, 86, 1351-1357. [CrossRef]

21. Kumar, S.; Cho, J.H.; Park, J.; Moon, I. Advances in diesel-alcohol blends and their effects on the performance and emissions of diesel engines. Renew. Sustain. Energy Rev. 2013, 22, 46-72. [CrossRef]

22. Amine, M.; Barakat, Y. Properties of gasoline-ethanol-methanol ternary fuel blend compared with ethanol-gasoline and methanol-gasoline fuel blends. Egypt. J. Pet. 2019, 28, 371-376. [CrossRef]

23. Imdadul, H.K.; Masjuki, H.H.; Kalam, M.A.; Zulkifli, N.W.M.; Alabdulkarem, A.; Rashed, M.M.; Ashrafu, A.M. Influences of ignition improver additive on ternary (diesel-biodiesel-higher alcohol) blends thermal stability and diesel engine performance. Energy Convers. Manag. 2016, 123, 252-264. [CrossRef]

24. Fan, C.; Song, C.; Lv, G.; Wang, G.; Zhou, H.; Jing, X. Evaluation of carbonyl compound emissions from a non-road machinery diesel engine fueled with a methanol/diesel blend. Appl. Therm. Eng. 2018, 129, 1382-1391. [CrossRef]

25. Kuszewski, H. Effect of adding 2-ethylhexyl nitrate cetane improver on the autoignition properties of ethanol-diesel fuel blend-Investigation at various ambient gas temperatures. Fuel 2018, 224, 57-67. [CrossRef]

26. Lin, C.-Y. Blending biodiesel in fishing boat fuels for improved fuel characteristics. Front. Energy Res. 2014, 2, 6. [CrossRef]

27. Hosseinzadeh-Bandbafha, H.; Tabatabaei, M.; Aghbashlo, M.; Khanali, M.; Demirbas, A. A comprehensive review on the environmental impacts of diesel/biodiesel additives. Energy Convers. Manag. 2018, 174, 579-614. [CrossRef]

28. Greenacre, M.; Primicerio, R. Multivariate Analysis of Ecologic Data; Fundacion BBVA: Bilbao, Spain, 2013.

29. Zuur, A.; Ieno, E.N.; Smith, G.M. Analysing Ecological Data; Springer: New York, NY, USA, 2007; p. 667.

30. Oksanen, J.; Guillaume Blanchet, F.; Friendly, M.; Kindt, R.; Legendre, P.; McGlinn, D.; Minchin, P.R.; O'Hara, R.B.; Simpson, G.L.; Solymos, P.; et al. vegan: Community Ecology Package. R package version 2.5-6. 2019. Available online: https://CRAN.R-project.org/package=vegan (accessed on 1 September 2019).

31. Kassambara, A.; Mundt, F. factoextra: Extract and Visualize the Results of Multivariate Data Analyses. R package version 1.0.7. 2020. Available online: https:/CRAN.R-project.org/package=factoextra (accessed on 1 April 2020).

32. Pohlert, T. PMCMRplus: Calculate Pairwise Multiple Comparisons of Mean Rank Sums Extended. R package version 1.4.4. 2020. Available online: https://CRAN.R-project.org/package=PMCMRplus (accessed on 12 September 2020).

33. Duraisamy, G.; Rangasamy, M.; Govindan, N. A comparative study on methanol/diesel and methanol/PODE dual fuel RCCI combustion in an automotive diesel engine. Renew. Energy 2020, 145, 542-556. [CrossRef]

34. Tian, J.; Tan, J.; Hu, N.; Liu, T.; Wang, Y.; Zhong, H. Characteristics analysis for total volatile organic compounds emissions of methanol-diesel fuel. J. Energy Inst. 2018, 91, 527-533. [CrossRef]

35. Mat Yasin, M.H.; Mamat, R.; Yusop, A.F.; Rahim, R.; Aziz, A.; Shah, L.A. Fuel Physical Characteristics of Biodiesl Blend Fuels with Alcohol as Additives. Procedia Eng. 2013, 53, 701-706. [CrossRef] 
36. Bhale, P.V.; Deshpande, N.V.; Thombre, S.B. Improving the low temperature properties of biodiesel. Renew. Energy 2009, 34, 794-800. [CrossRef]

37. Singh, D.; Sharma, D.; Soni, S.L.; Sharma, S.; Kumar Sharma, P.; Jhalani, A. A review on feedstocks, production processes, and yield for different generations of biodiesel. Fuel 2019, 262, 116553. [CrossRef] 